„Bohemistyka” 2021, nr 3, ISSN 1642-9893

Martin JANEČKA

Univerzita Karlova

\section{Frekvence pádu v projevech afatických osob ve vztahu k používání gestikulace: srovnání s osobami bez diagnostikované poruchy řeči}

Keywords: aphasia, gestures, case, frequency analysis, syntax

Klíčová slova: afázie, gesta, pád, frekvenční analýza, syntax

\section{Abstract}

The article deals with a comparison of frequency of noun case in transcriptions of audio-visual recordings produced by people with diagnosed aphasia and people with no visible speech distortion. Considering case distribution in aphasic people's speech, this article tries to point out some specifics connected to general characteristics of aphasic speech. Further, frequency of autosemantic parts of speech (nouns, verbs and adverbs) in aphasic people's speech and verification persons is described. This frequency is further connected with number of communication gestures. Based on analysis of aphasic people speech, it is obvious that these gestures can not only accompany their speech, but they can also substitute different autosemantic parts of speech. Results show that, on the one hand, people with diagnosed aphasia use less autosemantic words, but on the other hand, they use more communication gestures than people without speech distortion.

Článek se zabývá srovnáním frekvence pádu substantiva $v$ přepisech audiovizuálních nahrávek osob s diagnostikovanou afázií a mluvčích bez diagnostikovaného poškození řeči. Pokouši se ukázat na některá specifika $\mathrm{v}$ distribuci pádů $\mathrm{v}$ projevech afatických osob, která souvisí s obecnou charakteristikou syntaxe afatických projevù. Dále postihuje frekvenci autosémantických slovních druhů (substantiv, sloves a adverbií) v projevech osob s afázií a standardních mluvčích a dává ji do souvislosti s počtem komunikačních gest, kterými je možné tyto autosémantické slovní druhy nejen doprovázet, ale také nahradit. Výsledky ukazují, že osoby s afázií používají na jednu stranu méně autosémantik, na druhou stranu však více komunikačních gest než standardní mluvčí.

\section{1. Úvod}

Kategorii pádu je v české lingvistické bohemistice věnováno mnoho prostoru, byt' dosud byla pozornost zaměřena zejména na výzkum psaných textů, at' už z oblasti funkčního stylu publicistického (Bláha 2017; Bláha, Janečka 2020) nebo např. odborného (Ledvina 2020). Pokud se ve výzkumu pádu (konkrétně genitivu adnominálního) jednalo o sondu do jazyka mluveného, byl materiálem korpus, v př́ípadě studie Janečky a Kouklíkové (2020) Oralv1.

Projevy afatických osob zatím v češtině př́iliš zkoumány nebyly, po průkopnících v tomto tématu R. Jakobsonovi (1995 aj.) a H. Lehečkové (2016 aj.) patř́i k výjimkám E. Flanderková (nejnověji 2019) nebo M. Láznička (2016), žádný z výzkumů se však nevěnoval specificky kategorii pádu substantiva, nadto ve srovnání s produkcí neverbálních prostředků, resp. gest v užším smyslu slova. Právě autentičnost materiálu a jeho nestandardnost je výzvou, kterou si výzkum nastíněný v tomto článku klade.

Po kapitole shrnující poznatky o pádovém systému češtiny uvádím základní charakteristiku afázie a její další členění na základě tzv. bostonské klasifikace. V dalších kapitolách nejprve nastiňuji klasifikaci gest použitou pro tento výzkum, dále popisuji proces sběru dat a svůj výzkumný vzorek sestávající z šesti mluvčích češtiny s diagnostikovanou afázií a deseti tzv. kontrolních osob, tedy mluvčích češtiny bez diagnostikované poruchy řeči.

V první části popisující zjištěná data se věnuji frekvenci autosémantických slovních druhů vzhledem k celkovému počtu slov u obou sledovaných skupin, v druhé části popisující zjištěná data pak distribuci pádu v projevech obou sledovaných skupin s důrazem na specifika v užívání konkrétních pádů afatickými mluvčími.

Je třeba předeslat, že tento výzkum je teprve v počátcích, nečiní si tedy žádné nároky na úplnost popisu - jde především o prvotní sondu a náznak, jakým směrem by se mohl výzkum kategorie pádu v přepisech autentického materiálu v souvislosti s jeho neverbální složkou ubírat.

332 


\section{Pád}

Vzhledem k tomu, že čeština patř́ mezi jazyky s bohatou flexí, je kategorie pádu často diskutovaným tématem nejen na stránkách mnoha časopisů, nýbrž i v samostatných monografiích. Např. Uličný a Veselovská (2017) pád nahlížejí jako gramatickou kategorii, která vyjadřuje vztah mezi jménem a dalším výrazem ve větě, kterým je toto jméno řízeno. Uvádějí, že je třeba lišit pád povrchový (morfologický) od jeho př́slušné funkce neboli pádu hloubkového. Ve flektivních jazycích, jakým je např. čeština, je pádový sém realizován v deklinačním morfu spolu se sémy čísla, rodu a potenciálně i životnosti. Výrazovým prostředkem pádového vztahu je ve flektivních jazycích především morfologický pád, tedy tvarotvorný sufix společně s předložkou (pád předložkový), nebo pád předložkou neurčený (bezpředložkový). V češtině je možno počítat se sedmi pády pro obě čísla (singulár i plurál), avšak vokativ bývá $\mathrm{z}$ definice pádu uvedené výše vydělován, jelikož sám o sobě nemůže být považován za větotvorný.

Podle autorů (Uličný, Veselovská 2017) je pádový systém českého jazyka ve své vývojové dynamice ovlivňován dvěma faktory vyplývajícími z tzv. intelektualizace jazyka. Na jedné straně jsou to analytizační procesy, tedy nahrazování prostých pádů pomocí pádů předložkových, což může mít souvislost se snahou vyjadřovat se přesněji a explicitněji. Na druhé straně jsou to vnitrojazykové aspekty projevující se tíhnutím $\mathrm{k}$ syntaktizaci pádů a rovněž substituováním periferních pádů, které disponují výraznější sémantikou (genitiv, dativ, instrumentál), pády strukturními (nominativ, akuzativ). Uličný (2003 aj.) pak vidí jako důsledek výše zmíněných faktorů ve vývojové dynamice současné spisovné češtiny určité tendence $\mathrm{k}$ deflektivizaci.

\section{Afázie}

Jak už bylo předesláno v úvodu, není mnoho výzkumů, které by $\mathrm{v}$ českém prostředí systematicky analyzovaly specifika mluvy osob s diagnostikovanou afázií. Důvodem mohou být jednak potenciální etické problémy týkající se pořizování záznamu afatických osob, dále jejich vůle participovat na lingvistickém výzkumu a v neposlední řadě sama náročnost zpracování takových projevů, vyznačujících se syntaktickou neuspořádaností, častými odbočkami od tématu, opravami, přeřeknutími, neologismy, ${ }^{1}$ opakováním slov, nesrozumitelností danou často zhoršenou schopností artikulovat atd.

Afázie je definována jako získaná porucha porozumění a produkce řeči vznikající jako důsledek mozkové léze (Cséfalvay 2013, 83n.), př́ččnami pak jsou léze v oblasti mozkové kůry, přičemž jde o vůbec nejčastější cerebrovaskulární onemocnění. Takové cévní mozkové př́hody (neboli CMP) jsou důsledkem uzávěru či zúžení mozkových arterií, což souvisí s nedostatečným zásobením mozku krví. Základními dvěma typy jsou afázie Brocova a Wernickeho, dalšími typy jsou pak např. afázie konduktivní, transkortikální motorická, transkortikální senzorická a další. Nutno dodat, že typy afázií se často překrývají a symptomy jednotlivých typů afázií mohou být a často i bývají pozorovatelné u jedné a téže osoby. Následující tabulka č. 1 ukazuje zřejmě nejrozšířenější typologii afázií na základě tzv. bostonské klasifikace. Sledovány jsou čtyři proměnné (schopnost spontánního projevu, schopnost porozumět řeči, schopnost opakování slyšeného a pojmenování různých entit jmény), prričemž kombinací těchto proměnných se ustavuje daný typ afázie.

Tabulka 1. Bostonská klasifikace afázií (Cséfalvay 2013, s. 18)

\begin{tabular}{||c|c|l|l|l||}
\hline $\begin{array}{c}\text { Klinický } \\
\text { syndrom }\end{array}$ & $\begin{array}{c}\text { Spontánní } \\
\text { řě }\end{array}$ & $\begin{array}{c}\text { Porozumění } \\
\text { řeči }\end{array}$ & Opakování & Pojmenování \\
\hline Brocova afázie & nonfluentní & $\begin{array}{l}\text { lehké až těžké } \\
\text { poruchy }\end{array}$ & narušeno & narušeno \\
\hline $\begin{array}{l}\text { Transkortikální } \\
\text { motorická }\end{array}$ & nonfluentní & $\begin{array}{l}\text { lehké až } \\
\text { středně } \\
\text { těžké poruchy }\end{array}$ & $\begin{array}{l}\text { nenarušeno/ } \\
\text { /lehce } \\
\text { narušeno }\end{array}$ & narušeno \\
\hline
\end{tabular}

\footnotetext{
${ }^{1}$ Nikoliv ve smyslu nové lexikální jednotky přejaté např. z cizího jazyka do češtiny, nýbrž modifikace posloupnosti fonémů často již existujících slov a tím vytváření slov úplně nových, př́jemci mnohdy nesrozumitelných.
} 


\begin{tabular}{||l|l|l|l|l||}
\hline \hline $\begin{array}{l}\text { Wernickeho } \\
\text { afázie }\end{array}$ & fluentní & těžce narušeno & narušeno & narušeno \\
\hline $\begin{array}{l}\text { Konduktivní } \\
\text { afázie }\end{array}$ & fluentní & lehce narušeno & $\begin{array}{l}\text { výrazně } \\
\text { narušeno }\end{array}$ & lehce narušeno \\
\hline
\end{tabular}

\section{Klasifikace gest}

Výzkum gest jako nedílného doprovodu verbálních vokálních prostředků se i díky moderním technologií rozvíjí zejména v posledních třech dekádách, za průkopnické jsou považovány mj. práce $\mathrm{D}$. McNeilla (1992) nebo A. Kendona (2004). V tomto článku přebírám klasifikaci ustavenou německou badatelkou K. Hogrefeovou ${ }^{2}$ (2009).

Gesta je podle Hogrefeové možné dělit na dvě základní funkční oblasti: gesta s komunikační funkcí a gesta s nekomunikační funkcí. Ke gestům komunikačním náleží především pohyby rukou, které jsou realizovány od těla na dálku, pohyby hlavy (např. kývání) či pohyby rameny (např. krčení ramen). K nekomunikačním gestům pak náleží především dotýkání se sebe sama s pouhou autostimulační funkcí.

K tzv. piktografům (neboli gestům ikonickým), kterými jsou ilustrovány různé předměty a pohyby, náleží na jednu stranu ikonografy, které slouží ke kreslení určitého objektu ve vzduchu, na druhou stranu pak kinetografy, kterými bývá znázorněno, jakým způsobem nebo jak rychle se nějaké subjekty pohybují. Deiktická (ukazovací) gesta lze pak vymezit jako další, samostatnou skupinu, přičemž dále můžeme rozlišit konkrétní deiktická gesta s funkcí ukazovat na nějaký konkrétní objekt $\mathrm{v}$ prostoru, nebo abstraktní deiktická gesta, pomocí nichž ukazujeme na nějaký prázdný prostor, když popisujeme nějakou imaginární scénu. Třetí podskupinou gest s komunikační funkcí jsou tzv. emblémy, tedy gesta formálně a významově striktně specifikovaná, přičemž jejich význam je ustaven konkrétním jazykem a konkrétními kulturně-společenskými podmínkami. Sem by patřilo např. salutování

${ }^{2}$ Podrobnější náhled na funkci gest u osob s afázií, založený na výzkumu z německého prostředí, byl představen v článku Janečky (2016). nebo „V“ naznačené ukazováčkem a prostředníčkem jako typický symbol pro vítězství (victory). Pro účely svého výzkumu shrnuji piktografy, deiktická gesta a emblémy do jedné skupiny, kterou nazývám gesta komunikační - pod tato komunikační gesta pak řadím ještě gesta tzv. procesuální (někdy nazývána též metaforická, např. McNeill 1992), která často doprovázejí slovesa s ne př́liš konkrétní sémantikou jako pracovat, dèlat, pomáhat apod. (na rozdíl od konkrétních sloves jako vařit, stř́let nebo plavat, která bývají znázorňována jasně ikonickými gesty). Do komunikačních tedy patří všechna gesta, která mohou přenášet význam a která mohou být použita jako substitut lexikálního vyjádření.

\section{Popis sběru dat}

Mluvčí bez diagnostikované poruchy řeči byli nahráváni za stejných podmínek jako osoby s afázií. Všem participantům byl k podpisu předložen formulář informovaného souhlasu, poté sledovali 24 minut (čtyři díly po šesti minutách) animované pohádky Shaun the Sheep ${ }^{3}$ a následně o ději $v$ těchto čtyrech epizodách vedl iniciátor projektu $\mathrm{s}$ respondenty rozhovor $\mathrm{v}$ délce přibližně 23 minut. Na popisu gestických prostředků participoval autor tohoto článku a dva asistenti $\mathrm{z}$ řad studentů, kteří byli předem zaškoleni. $\mathrm{V}$ rámci mezianotátorské shody bylo nutné, aby se na všech proměnných v popisu audiovizuálního materiálu vždy shodli alespoň dva anotátoři ze tř́i.

\subsection{Popis participantů výzkumu}

V následující tabulce je popsáno šest osob s diagnostikovanou afázií, které participovaly na výzkumu. Uvedeno je jejich pohlaví,

\footnotetext{
${ }^{3}$ Výběr této pohádky byl inspirován zahraničními studiemi na podobné téma tyto studie jako argument pro výběr tohoto typu pohádky uvádějí jako nejvýraznější výhodu to, že se v pohádce nepoužívá žádný jazyk, tudíž osoby, které mají následně za úkol př̀evyprávět děj pohádky, se nemohou opřít o žádný slyšený základ a převypráví děj striktně vlastními slovy.
} 
věk, nejvyšší dosažené vzdělání, doba trvání afázie a převládající typ afázie. Co se týká kontrolního vzorku deseti osob bez diagnostikované poruchy řeči, figuruje ve výzkumném vzorku pět mužů (M1 až M5) a pět žen (Z1 až Z5) mezi 20 a 40 lety, všichni s vysokoškolským vzděláním. Jsem si vědom toho, že z hlediska sociolingvistických parametrů by bylo ideální, kdyby si vzorky osob s afázií a osob bez afázie odpovídaly, tedy kdyby jej tvořili lidé stejného nebo alespoň podobného věku, s podobným dosaženým vzděláním a kdyby byl vzorek genderově vyvážený. Zajistit korespondenci těchto parametrů je však velmi náročné, jelikož osoby s afázií jsou často spíše starší (nejmladšímu je 46 let, průměrný věk je pak 64 let) a ve vzorku převažují muži, kdežto do kontrolního vzorku se v rámci výzkumu nepřihlásila žádná osoba starší 40 let. Zajištěn je tak pouze jeden parametr shodný u všech participantů - jsou mluvčími obecné češtiny.

Zatímco pět ze šesti osob s afázií bylo nahráváno ve svém domácím prostř̌edí a pouze jeden participant v klubovně Klubu afasie, ${ }^{4}$ všechny kontrolní osoby byly nahrávány v univerzitním prostředí za naprosto stejných podmínek.

Tabulka 2. Údaje o osobách s afázií

\begin{tabular}{||l|c|c|c|c|l||}
\hline \hline \multicolumn{1}{|c|}{ Osoba } & Pohlaví & Věk & Vzdělání & Trvání afázie & \multicolumn{1}{|c||}{ Typ afázie } \\
\hline 1 (MB1) & muž & 69 & VŠ & 9 let & Brocova \\
\hline $2(\mathrm{MB} 2)$ & muž & 67 & $\mathrm{SŠ}$ & 20 let & Brocova \\
\hline $3(\mathrm{Ztm})$ & žena & 56 & vyučena & 3 roky & $\begin{array}{l}\text { transkortikální } \\
\text { motorická }\end{array}$ \\
\hline $4(\mathrm{MW} 2)$ & muž & 79 & VŠ & 4 roky & $\begin{array}{l}\text { Wernickeho/ } \\
\text { konduktivní }\end{array}$ \\
\hline $5(\mathrm{Mtm})$ & muž & 46 & VŠ & 5,5 roku & $\begin{array}{l}\text { transkortikální } \\
\text { motorická }\end{array}$ \\
\hline $6(\mathrm{MW} 1)$ & muž & 71 & vyučen & 3,5 roku & Wernickeho \\
\hline
\end{tabular}

${ }^{4}$ Nezisková organizace působící v Praze 6 a poskytující svým klientům sekundární terapii nad rámec jejich terapie primární. Za pomoc s organizací nahrávání a další cenné podněty děkuji Mgr. Zuzaně Konůpkové, předsedkyni spolku Klub afasie z.s.
Vysvětlivky:

MB1 = muž č. 1 s Brocovou afázií, MB2 = muž č. 2 s Brocovou afázií, MW1 = muž č. $1 \mathrm{~s}$ Wernickeho afázií, MW2 = muž č. $2 \mathrm{~s}$ Wernickeho afázií, Mtm = muž s transkortikální motorickou afázií, Ztm = žena s transkortikální motorickou afázií.

\section{Vliv gest na frekvenci autosémantických slovních druhů}

V tabulkách jsou započítána pouze tzv. komunikační gesta, která je možno spojit s přenesením nějaké informace, tedy gesta ikonická (ikonografy a kinetografy v klasifikaci K. Hogrefeové, 2009), deiktická $^{5}$ a tzv. procesuální (metaforická). Nejsou zde uvedeny gestické projevy informace nepřenášející, tedy tzv. organizátory diskurzu, jako např. mávnutí ruky na znamení, že mluvčí dokončil svou výpověd', nebo tzv. gesta autostimulativní, např. škrabání se na hlavě, na bradě nebo na nose $\mathrm{v}$ př́padě nervozity atp.

Ze slovních druhů se soustředím na substantiva, kterými jsou popisovány, pojmenovávány určité entity (předměty, osoby, př́rodní jevy atp.), dále na slovesa, která slouží k popisu činností, a na adverbia, kterými se vyjadřují mj. prostorové vztahy, na něž byly ukázky animované pohádky Shaun the Sheep obzvláště zaměřeny. Ve výčtu sledovaných autosémantik schází adjektiva, která podle mých předběžných pozorování nejsou propojena s gestikulací do takové míry jako substantiva, slovesa a adverbia, tudíž nedochází až na ojedinělé př́ípady $\mathrm{k}$ substituci adjektiva nějakým gestem at’ už u osob $\mathrm{s}$ afázií nebo u standardních mluvčích.

5 Aby byla Peircova sémiotická triáda kompletní, je nutné zmínit ještě gesta symbolická (neboli emblémy), ty se však ve sledovaných datech vůbec neobjevují. Důvodem je u afatických osob jednak to, že potřebují pomocí gest přenést co nejvíce informace a nespoléhají se tak na to, že bude rozpoznán konvenční význam symbolického gesta, jednak u obou sledovaných skupin to, že symbolická gesta nejsou třeba k tak specifickému úkolu, jako je převyprávět děj animované pohádky. Participanti si tak vystačí pouze s použitím gest ikonických a deiktických, příp. s pomocí gest poukazujících na nějaký význam (gesta procesuální). 
Tabulka 3. Frekvence autosémantik v poměru ke gestům u osob s afázií

\begin{tabular}{|l|c|c|c|c|c||}
\hline Osoba & $\begin{array}{c}\text { Slov } \\
\text { celkem }\end{array}$ & $\begin{array}{c}\text { SUBS } \\
(\mathbf{v} \%)\end{array}$ & $\begin{array}{c}\text { VERB } \\
\mathbf{( v ~ \% )}\end{array}$ & $\begin{array}{c}\text { ADV } \\
\mathbf{( v ~ \% )}\end{array}$ & $\begin{array}{c}\text { Gest } \\
\text { celkem }\end{array}$ \\
\hline Mtm & 1086 & $189(17,4)$ & $197(18,1)$ & $106(9,8)$ & 40 \\
\hline Ztm & 818 & $112(13,7)$ & $185(22,6)$ & $104(12,7)$ & 22 \\
\hline MB2 & 750 & $135(18)$ & $128(17,1)$ & $64(8,5)$ & 53 \\
\hline MW1 & 733 & $93(12,7)$ & $177(24,1)$ & $105(14,3)$ & 19 \\
\hline MW2 & 580 & $61(10,5)$ & $145(25)$ & $69(11,9)$ & 68 \\
\hline MB1 & 578 & $63(10,9)$ & $59(10,2)$ & $106(18,3)$ & 119 \\
\hline
\end{tabular}

Tabulka 4. Frekvence autosémantik v poměru ke gestům u standardních mluvčích

\begin{tabular}{||l|l|l|l|l|c||}
\hline Osoba & $\begin{array}{c}\text { Slov } \\
\text { celkem }\end{array}$ & $\begin{array}{c}\text { SUBS } \\
\mathbf{( v ~ \% )}\end{array}$ & $\begin{array}{c}\text { VERB } \\
\mathbf{( v ~ \% )}\end{array}$ & $\begin{array}{c}\text { ADV } \\
\mathbf{( v ~ \% )}\end{array}$ & $\begin{array}{c}\text { Gest } \\
\text { celkem }\end{array}$ \\
\hline Z1 & 3563 & $510(14,3)$ & $773(21,7)$ & $447(12,5)$ & 38 \\
\hline M2 & 3368 & $625(18,6)$ & $692(20,5)$ & $455(13,5)$ & 112 \\
\hline Z4 & 3056 & $454(14,9)$ & $621(20,3)$ & $531(17,4)$ & 59 \\
\hline M5 & 3010 & $498(16,4)$ & $627(20,8)$ & $410(13,6)$ & 133 \\
\hline Z2 & 2923 & $357(12,2)$ & $592(20,3)$ & $611(20,9)$ & 150 \\
\hline M1 & 2720 & $425(15,6)$ & $477(17,5)$ & $308(11,3)$ & 51 \\
\hline M4 & 2376 & $399(16,8)$ & $466(19,6)$ & $406(17,1)$ & 36 \\
\hline Z3 & 2151 & $351(16,3)$ & $441(20,5)$ & $317(14,7)$ & 75 \\
\hline M3 & 2104 & $368(17,5)$ & $395(18,8)$ & $256(12,2)$ & 33 \\
\hline Z5 & 1903 & $275(14,5)$ & $345(18,1)$ & $321(16,9)$ & 34 \\
\hline
\end{tabular}

Ze srovnání dat v tabulkách č. 3 a 4 je evidentní, že mezi projevy osob s afázií a projevy standardních mluvčích existují významné rozdíly, ale i částečné shody. Tak např. Mtm se frekvencí substantiv a sloves k celkovému počtu slov přibližuje ke standardním mluvčím. Podobně jediná žena zahrnutá do výzkumu, Ztm s transkortikálně motorickou afázií, vykazuje vyšší hodnoty autosémantik, zejména u sloves. Vyšší hodnoty jsou pak překvapivě i u muže MB2, který, ač diagnostikován s Brocovou afázií, vykazuje třetí nejvyšší úhrn slov celkem a s tím korespondující vyšší hodnoty autosémantik. U dvou Wernickeho afatiků je pak výrazně vyšší frekvence sloves, naopak snížená je schopnost používat substantiva, což koresponduje s obecnou charakteristikou těchto afatiků spočívající ve značně snížené schopnosti pojmenovávat věci, předměty, osoby atp. U sloves lze konstatovat, že se naměřené hodnoty vzhledem $\mathrm{k}$ celkovému počtu slov pohybovaly u afatických osob mezi 17 až 24 procenty, což koresponduje i s osobami kontrolními. U sloves byly vůbec nejnižší hodnoty zjištěny u muže s Brocovou afázií, MB1, což lze vysvětlit tak, že nedokázal jednak pojmenovat různé entity konkrétními substantivy, jednak nedokázal pojmenovat činnosti, které byli těmito entitami prováděny.

Adverbia naproti tomu u MB1 tvoř́i 18 procent jeho projevu, což souvisí s častým používám zájmen a př́islovečných určení v doprovodu komunikačních, plně sémantických gest tam, kde by se v úplné výpovědi nacházel i subjekt, verbum a objekt, tak např. On tam...nahoře... [+ neverbální naznačení věšení něčeho nad sebou] namísto Muž pověsil obraz na zed' atp. U adverbií lze konstatovat, že kromě MB1 se jejich frekvence u afatiků pohybuje v rozmezí 9 až 14 procent, což je méně než u kontrolních osob, kde se hodnoty pohybují od 11 do 20 procent. Co se týká počtu komunikačních gest identifikovaných u jednotlivých participantů, naprosto dominuje právě MB1, který pomocí gest nejen naznačoval vzájemné prostorové vztahy různých entit, ale také ilustroval entity samotné a činnosti, které byly těmto entitám připisovány.

\section{Pád substantiva v projevech afatických osob a standardních mluvčích}

Tabulka 5. Frekvence pádu substantiva v promluvách osob s afázií

\begin{tabular}{|l|c|c|c|c|c|c||}
\hline Osoba & N & G & D & A & L & I \\
\hline MB1 & 61 & 1 & & & & 1 \\
\hline MB2 & 102 & 3 & & 23 & 4 & 3 \\
\hline
\end{tabular}




\begin{tabular}{|l|r|r|r|r|r|l||}
\hline Mtm & 86 & 17 & 6 & 61 & 11 & 8 \\
\hline MW1 & 35 & 8 & 6 & 42 & & 2 \\
\hline MW2 & 47 & 1 & & 10 & 2 & 1 \\
\hline Ztm & 65 & 10 & & 32 & 2 & 3 \\
\hline
\end{tabular}

Údaje zachycené $\mathrm{v}$ tabulce č. 5 lze interpretovat tak, že jméno $\mathrm{v}$ promluvách afatických osob téměř vůbec nevstupuje do syntaktických vztahů, nachází se takřka výhradně ve svém základním pádu. Jelikož osoby s afázií nevytvářejí delší konstrukce, lze na základě toho tvrdit, že jména se často nacházejí osamoceně, nejsou nijak syntakticky vázána. Akuzativ, který konkuruje nominativu co do frekvence v projevech standardních mluvčích jakožto pád přímého objektu, se tedy v promluvách osob s afázií vyskytuje výrazně méně. Za pozornost jistě stojí i absence dativu u čtyř afatických mluvčí ze šesti. Důvodem může být to, že dativ je primárně pádem druhého předmětu a takto syntakticky náročné konstrukce produkují mluvčí s afázií pouze marginálně.

Tabulka 6. Frekvence pádu substantiva ve vzorku standardních mluvčích

\begin{tabular}{|l|c|c|c|c|c|c||}
\hline Osoba & N & G & D & A & I & L \\
\hline Z1 & 191 & 62 & 16 & 162 & 40 & 36 \\
\hline M1 & 120 & 48 & 10 & 118 & 61 & 68 \\
\hline Z2 & 109 & 34 & 14 & 131 & 37 & 31 \\
\hline M2 & 222 & 86 & 27 & 197 & 53 & 39 \\
\hline M3 & 121 & 58 & 16 & 115 & 29 & 29 \\
\hline Z3 & 130 & 31 & 14 & 110 & 25 & 36 \\
\hline Z5 & 109 & 26 & 10 & 91 & 19 & 20 \\
\hline Z4 & 155 & 66 & 16 & 146 & 31 & 27 \\
\hline M4 & 123 & 66 & 14 & 118 & 33 & 45 \\
\hline M5 & 159 & 47 & 31 & 176 & 51 & 33 \\
\hline
\end{tabular}

Jak můžeme odvodit $\mathrm{z}$ tabulek č. 3 a č. 4, ve frekvenci slovních druhů $\mathrm{v}$ poměru $\mathrm{k}$ celkovému objemu slov $\mathrm{v}$ participantově narativu zásadní rozdíly až na několik málo výjimek nejsou ${ }^{6}$. Zásadnějších odlišností mezi projevy osob s afázií a projevy standardních mluvčích si lze všimnout ve frekvenci jednotlivých pádů vzhledem $\mathrm{k}$ celkovému objemu slov v participantově narativu.

$\mathrm{Z}$ údajů zachycených tabulkou č. 6 je patrné, že na rozdíl od promluv osob s afázií je v promluvách standardních mluvčích daleko více přitomen lokál a instrumentál, tedy pády, které se v promluvách osob $\mathrm{s}$ afázií vyskytují pouze $\mathrm{v}$ rádu jednotek. Lze tak usuzovat, že právě lokál a instrumentál jsou u osob s afázií nahrazeny gestikulací, jelikož lokál slouží do značné míry $\mathrm{k}$ popisu prostorových vztahů, instrumentálem se pak popisují prostředky, kterými se vykonává nějaká činnost.

Čtyři afatičtí mluvčí jsou co do frekvence substantiv v poměru k celkovému objemu slov za poslední z kontrolních osob, další dva se však nacházejí na celkovém 2., resp. 4. místě ze všech participantů, afatických i neafatických. Co se týká konkrétních pádů substantiva, velmi omezen nebo dokonce chybějící je u afatikủ L, I a $D$, částečně omezen je i G, zůstává pouze $\mathrm{N}$ a $\mathrm{A}$, tedy pády prrímé, syntaktické, které plní funkci subjektu a primárního objektu. Jiné větné členy u sledovaných afatiků identifikovat nelze, at' už se jedná o neshodný př́vlastek v podobě $\mathrm{G}$ adnominálního, druhý předmět (dativ) nebo adverbiale (lokál, instrumentál), nevyskytuje se však ani doplněk, který bývá standardně také v instrumentálu. Všechny tyto poznatky tedy korespondují s obecnou definicí syntaxe osob $\mathrm{s}$ afázií jako značně zjednodušené, neuspořádané, bez složitěji vyjadřovaných vztahů mezi větnými členy.

${ }^{6} \mathrm{~K}$ základním plnovýznamovým druhům ještě zbývá doplnit poznámku o adjektivech - jak u osob s afázií, tak u osob bez afázie byla frekvence adjektiv v jejich narativech přibližně třetinová až čtvrtinová oproti adverbiím, nepovažoval jsem tedy vzhledem $\mathrm{k}$ tomu za nutné realizovat pro ně samostatnou kolonku. 


\section{Závěr}

V tomto článku jsem si za cíl kladl prozkoumat vztah mezi frekvencí slovních druhů, pády substantiva a komunikačními gesty v projevech osob $\mathrm{s}$ afázií v porovnání s projevy standardních mluvčích. Zjistil jsem, že až na některé odchylky odpovídá rámcová klasifikace afázií popsaná v úvodu článku (s pomocí tzv. bostonské klasifikace) jevům pozorovaným při přepisu audiovizuálního záznamu řeči českých mluvčích s diagnostikovanou afázií.

V oblasti pádové distribuce bylo zjištěno, že osoby s afázií na rozdíl od standardních mluvčích nevyuživají celé spektrum pádové soustavy češtiny, nýbrž převážně jen pády prímé, syntaktické - zejména nominativ (jakožto pád subjektu) a částečně i akuzativ. Pády, pomocí nichž jsou popisovány prostorové vztahy entit nebo činnosti prováděné pomocí různých prostředků, tedy zejména lokál a instrumentál, jsou pak osobami s afázií využívány pouze marginálně, oproti standardním mluvčím pak afatici téměř nerealizují další složitější syntaktické vztahy ve větě, resp. výpovědi, jako je např. doplněk, druhý předmět nacházející se $\mathrm{v}$ dativu nebo genitivem adnominálním realizovaný neshodný př́ivlastek.

Afatičtí mluvčí měli problémy zejména s pojmenováním různých entit substantivy, naopak v produkci sloves se př́liš neodchylovali od mluvčích češtiny bez diagnostikované poruchy řeči. Dálo bylo zjištěno, že osoby s nejnižším řečovým handicapem používají nejnižší množství tzv. komunikačních gest, naopak osoby s nejvýraznějším handicapem (zejména jeden ze dvou Brocových afatiků, MB1) používají značné množství komunikačních gest $\mathrm{k}$ tomu, aby nahradili chybějící verbální vokální vyjádření at' už pro určité sloveso, či spíše pro určité substantivum. Nejvíce přitom tito mluvčí použivají zcela konkrétní, ikonická gesta, v menší míře pak gesta deiktická (ukazovací), vůbec pak nepoužívají gesta symbolická (emblémy), která jsou založena na konvenci a nezajištujú tak jasné předání významu.

\section{Literatura}

B lá ha O., 2017, Syntaktické funkce pádu v češtině (na materiálu publicistických textů z roku 1915 a 2015). In O. Uličný (ed.), Struktura v jazyce, jazyk $v$ komunikaci. Liberec: Technická univerzita, s. 17-25.

B lá h a O., J a n e č k a M., 2020, Genitiv adnominální v češtině - vývoj a současný stav. Olomouc: Univerzita Palackého v Olomouci.

C s éfalv a Z Z., Le chta V. a kol., 2013, Diagnostika narušené komunikačni schopnosti u dospélých. Praha: Portál.

C s é f a 1 v a y Z., 2007, Terapie afázie: teorie a prripadové studie. Praha: Portál.

F 1 a n d e r k o vá E., 2019, Čeština v afázii: teorie a empirie. Praha: Karolinum.

H o g r e fe K., 2009, Aphasie, Apraxie und Gestik: Zur Produktion von Handgesten bei Patienten mit linkhemisphärischer Hirnschädigung. Nepublikovaná disertační práce. Potsdam: Universität Potsdam.

J a k o b s o n R., 1995, Dva aspekty jazyka a dva typy afatických poruch. In R. Jakobson: Poetická funkce. Praha: H\&H, s. 55-73.

J a n e č k a M., 2016, Gestika a afázie: paralely $v$ omezenich jazyka a gest. „Lingvistika Paraha”. Online: http://lingvistikapraha.ff.cuni.cz/sbornik.

Janečka M., Kouklíková T., 2020, Ke konkurenci genitivu posesivního a individuálně posesivnich adjektiv v současné mluvené češtině, ,Jazykovedný časopis“, č. 1, s. 69-89.

Ke nd on A., 2004, Gesture: Visible Action as Utterance. Cambridge: Cambridge University Press.

Lá znička M., 2016, Př́prava korpusu afatické češtiny. „Studie z aplikované lingvistiky/Studies in Applied Linguistics” 7, s. 184-187.

L e d v in a L., 2020, Sémantické typy genitivu adnominálního ve vybraných textech publikovaných v letech 2010-2019v časopise Český jazyk a literatura. Nepublikovaná magisterská diplomová práce, Praha: Pedagogická fakulta UK.

L e h e č k o vá H., 2016, Afázie v lingvistice, lingvistika v afáziologii. „Časopis pro moderní filologii” 98, č. 1, s. 7-22.

M c N e i 11 D., 1992, Hand and mind: What gestures reveal about thought. Chicago: University of Chicago Press.

U 1 i č n ý O., V e s e l o v s k á L. (2017). Pád. In P. Karlík, M. Nekula, J. Pleskalová (eds.), CzechEncy: Nový encyklopedický slovnik češtiny. Online: https://www.czechency.org/slovnik/PÁD [př́stup: 5. 3. 2019].

Uličný O. (2003): K deflektivizačním tendencím ve slovanských jazycích. In I. Pospíšil, M. Zelenka (eds.), Česká slavistika 2003. České přednášky pro XIII. mezinárodní kongres slavistů, Ljubljana 15.-21. 8. 2003. Praha: Academia, s. 155-163. 